\title{
Legal Analyses of the Compatibility of Anti-Dumping under the WTO in Contrast with Islamic Law and Saudi Arabia's Domestic Law
}

\author{
Abdullah M. Mattar ${ }^{1}$ \\ ${ }^{1}$ Brunel Law School, Brunel University London, Uxbridge, Middlesex, England \\ Correspondence: Abdullah M. Mattar, Brunel Law School, Brunel University London, Uxbridge, Middlesex, UB8 \\ 3PH, England. E-mail: Abdullah.Mattar@brunel.ac.uk
}

$\begin{array}{lc}\text { Received: April 3, } 2014 & \text { Accepted: April 24, } 2014 \quad \text { Online Published: May 28, } 2014 \\ \text { doi:10.5539/ilr.v3n1p66 } & \text { URL: http://dx.doi.org/10.5539/ilr.v3n1p66 }\end{array}$

\begin{abstract}
The subject matter of this paper is examination of anti-dumping rules, as expressed in the WTO agreement. Research delves in compatibility of the Islamic principles and Saudi Arabian law with WTO agreement on anti-dumping. In line with that, paper would manifest the legal vacuums, advantages and disadvantages of WTO agreement and current Saudi Arabian law previsions and principles to offer a proper legal approach to shield integration and harmonization between all of GCC member of states.
\end{abstract}

Keywords: anti-dumping, WTO agreement, Islamic principles and Saudi Arabian law

\section{Introduction}

This paper examines the anti-dumping law, ${ }^{1}$ as expressed in the WTO agreement, ${ }^{2}$ and then examines the extent to which similar rules apply in Islamic law and in Saudi Arabian domestic law. This examination takes place in order to answer one of the research questions to assess compatibility between Saudi Arabian national regulations and the WTO agreement on anti-dumping. This analysis will take place in reference to anti-dumping law under the WTO framework and discuss its implementation, as well as the main arguments and cases that have arisen under the Dispute Settlement Body (DUS). ${ }^{3}$

In order to examine compatibility between anti-dumping law under the WTO agreement and Saudi Arabian domestic law, it is important to determine whether anti-dumping rule are compatible with Islamic law. This is because Saudi Arabia cannot adopt regulations affecting its domestic legal system unless they are compatible with Islamic law, as stressed in its Basic Law of Governance, Article Seven "Governance in the Kingdom of Saudi Arabia derives its authority from the Book of God Most High and Sunnah of his Messenger, both which govern this law and all the laws of the state". ${ }^{4}$ However, this raises another question; i.e. can any country using Islamic law as its domestic legal system object to adding anti-dumping law to its domestic regulations.

Dumping law can be perceived as unfair competition ${ }^{5}$ or unfair trade practice; ${ }^{6}$ that is, they can directly affect free trade and the process of exchange between contracting parties. It is crucial to mention that this WTO agreement is a unique agreement as it is based on negotiations between contracting parties, which is different

\footnotetext{
${ }^{1}$ Agreement on Implementation of Article VI of the General Agreement on Tariffs and Trade 1994 (Anti-Dumping Agreement), 1868 U.N.T.S., 201.

${ }^{2}$ WTO Agreement: Marrakesh Agreement Establishing the World Trade Organization, Apr. 15, 1994, The Legal Texts: The Results of the Uruguay Round of Multilateral Trade Negotiations 4 (1999), 1867 U.N.T.S. 154, 33 I.L.M. 1144 (1994) [hereinafter Marrakesh Agreement or WTO Agreement].

${ }^{3}$ DSU, Dispute Settlement Rules: Understanding on Rules and Procedures Governing the Settlement of Disputes, Marrakesh Agreement Establishing the World Trade Organization, Annex 2, The Legal Texts: The Results of the Uruguay Round of Multilateral Trade Negotiations 354 (1999), 1869 U.N.T.S. 401, 33 I.L.M. 1226 (1994).

${ }^{4}$ Saudi Basic Law of Government (Consider the Saudi Constitution), Issued by the Royal Order number A/90 dated $1^{\text {st }}$ of March, 1992. The Bureau of Experts at the Saudi Council of Ministries, The Basic Law of Government, Retrieved from http://boe.gov.sa/ViewSystemDetails.aspx?lang=en\&SystemID $=4$

${ }^{5}$ Bossche, P. V. B. (2009). The Law and Policy of the World Trade Organization, (2 ${ }^{\text {nd }}$ ed.). Cambridge, England: Cambridge University Press.

${ }^{6}$ Bossche, P. V. B. \& Zdouc, W. (2013) The Law and Policy of the World Trade Organization (3 ${ }^{\text {rd }}$ ed.). Cambridge, England: Cambridge University Press.
} 
from other international agreements. However, anti-dumping legal actions globally could be an obstacle to the successful implementation of the WTO agreement.

This paper has been divided into five sections. Section one examines anti-dumping anti-subsidy regulations under the WTO agreement and implementation practices. It also discusses and analyses these in reference to their main tenets, in order to deliver a clear understanding of anti-dumping law. In section two, anti-dumping law will be examined in reference to Islamic law provisions, to provide an understanding of the extent of Islamic legal opinion concerning them. Section three, will analyse anti-dumping law as it manifests in Saudi Arabian domestic law. Moreover, section four will discuss the compatibility between anti-dumping law under the WTO agreement in reference to Islamic law and the Saudi Arabian domestic law. The final section concludes, presenting the results of all the examinations and the relevant analysis.

\section{Anti-Dumping under the WTO}

The Anti-Dumping Agreement (AD) is an Agreement describing the Implementation of Article VI of the General Agreement on Tariffs and Trade $1994,{ }^{7}$ which is often considered the most complex and technical provisions under the WTO Agreement. ${ }^{8}$ Dumping action refers to unfair competition in international markets, which may injure or threaten similar domestic products. Dumping itself is not unlawful, except where it causes injury to a similar domestic industry or threatens it. ${ }^{9}$ Yet, in some cases, dumping or anti-dumping duty can as a kind of circumvention, in which one country imposes a duty on another country; this then might bring to bear on other countries. This may then lead to one country then obtaining a concession, whether political or economic, based on an international decision.

The first country in the world to issue an anti-dumping rule was Canada in $1904 .{ }^{10}$ By the 1920 s, many other countries had issued these kinds of rules to protect their domestic market. ${ }^{11}$ According to international trade agreements rounds and after the adoption of anti-dumping law under GATT article $\mathrm{VI}^{12}$, contracting parties continued their interest in negotiations on anti-dumping in the Kennedy Round. ${ }^{13}$ Finally, the WTO Agreement issued implementation of Article VI of GATT 1994, stating dumping to be illegal. ${ }^{14}$

The number of anti-dumping cases has increased over the past 10 years. ${ }^{15}$ However, it cannot be considered that the AD Agreement has failed. In reality many things have changed in the world, especially in terms of trade, which might need to be reconsidered following this high number of cases.

\subsection{Definition of Dumping}

Some legal scholars characterise dumping as price discrimination between national markets; ${ }^{16}$ therefore, they consider it to be a form of unfair competition in international markets. However, this characterisation does not uniformly express a precise definition of dumping. To determine $\mathrm{AD}$, there must similarities between products also injury to those similar products or threat to the industry producing them. In such cases, the action of is a type or category of price discrimination.

Other researchers define dumping as the practice of selling a product for export at a price below its normal "Dumping arises from the pricing practices of exporters as both normal value and export prices reflect their

\footnotetext{
${ }^{7}$ Agreement on Implementation of Article VI of the General Agreement on Tariffs and Trade 1994 (Anti-Dumping Agreement), 1868 U.N.T.S. 201.

${ }^{8}$ Vermulst, E. (2008) The WTO Anti-agreement (1 $1^{\text {st }}$ ed.). Oxford, England: Oxford University Press.

${ }^{9}$ Bossche, P. V. B. (2009). The Law and Policy of the World Trade Organization, (2 $2^{\text {nd }}$ ed.). Cambridge, England: Cambridge University Press.

${ }^{10}$ Trebilcock, M. J. \& Howse, R. (2005) The Regulation of International Trade, ( ${ }^{\text {rd }}$ ed.). Routledge, New York, NY 10016.

${ }^{11}$ Aggarwal, A. (2007) The Anti-dumping Agreement and Developing Countries, an Introduction ( $1^{\text {st }}$ ed.). Oxford, England: Oxford University Press.

${ }^{12}$ General Agreement on Tariffs and Trade (GATT), 55 UNTS 194; 61 Stat. pt. 5; TIAS 1700, Article VI.

${ }^{13}$ Trebilcock, M. J. \& Howse, R. (2005) The Regulation of International Trade, ( ${ }^{\text {rd }}$ ed.). Routledge, New York, NY 10016.

${ }^{14}$ Agreement on Implementation of Article VI of the General Agreement on Tariffs and Trade 1994 (Anti-Dumping Agreement), 1868 U.N.T.S., 201.

${ }^{15}$ See the Anti-dumping cases under the Dispute Settlement Body, World Trade Organization, http://www.wto.org/

${ }^{16}$ Aggarwal, A. (2007) The Anti-dumping Agreement and Developing Countries, an Introduction ( $1^{\text {st }}$ ed.). Oxford, England: Oxford University Press.

${ }^{17}$ Bentley, P. \& Silberston, A. (2007) Anti-dumping Countervailing Action, limits Imposed by Economic and Legal Theroy ( $1^{\text {st }}$ ed.). Cheltenham, England: Edwers Elgar Publishing Limited.
} 
strategies in home and foreign markets". ${ }^{8}$ Yet, this definition focused on prices in general and the selling operation itself, which is not insufficient to define dumping.

It is suggested that the closest definition is "[the] bringing of a product onto the market of another country at a price less than the normal value of that product". ${ }^{19}$ For the purpose of this study, this definition is deemed the most accurate, in that it includes all details regarding dumping, so they can be understood clearly. However, points about similarities and injury or threat included, it would then be clearer and more comprehensive. The definition proposed to inform this research is: the bringing of a product onto the market of another country at a price less than the normal value of that product, thereby causing an injury or threat to the industry of the similar product.

Nonetheless, in the Appellate Body Report for US-Mexico Stainless Steel the definition of dumping, as stated in the anti-dumping agreement is:
"Dumping" is defined in Article VI: 1 of the GATT 1994 as occurring when a product of one country is introduced into the commerce of another country at less than its normal value. Article VI: 1 further states that dumping is to be "condemned" if it causes or threatens to cause material injury to the domestic industry producing a like product..., 20 In the other way, this similar product has to be destined for consumption in the exporting country "... a product is to be consider as being "dumped" if the "export price" of the product "exported" from one country to another is less than the comparable price of the "like" product when destined for consumption in the "exporting country.",2I

Yet, the same case referred to key elements of the dumping as:

The elements of the definition of "dumping" contained in Article VI: 1 of the GATT 1994 and Article 2.1 of the Anti-Dumping Agreement-namely, that "dumping" occurs when a product is "introduced into the commerce of another country" at an "export price" that less than the "comparable price for the like product in the exporting country"-suggest to us that Article VI: 1 of the GATT 1994 and Article 2.1 of the Anti-Dumping Agreement address the practicing of an exporter. ${ }^{22}$

Based on the previous statement, it can be seen that there are seven important elements that must be met as pre-conditions for dumping to be said to exist, and all seven conditions need to be present before anti-dumping can be alleged. They are as follows:

1. The product has to be exported "Introduced";

2. The product has to be from another country;

3. There has to be a market for competition between goods;

4. The product has to have a normal price and a lower price;

5. There have to be similarities between the products;

6. Differences in pricing must lead to injury or threat to similar products; and

7. There must be a causal link between low price and injury.

\subsection{Key Elements of Dumping}

The key elements involved in dumping, as mentioned above, are: exporting the product from another country, the competitive market, the price, domestic and imported products, and injury or threat to the domestic industry. This section includes an analysis of all these elements.

\subsubsection{Exporting Products from Another Country}

As defined above, to implement anti-dumping provisions in any case, the first point to consider is whether the product is being imported from another country. In other words: “...introduced into the commerce of another

\footnotetext{
${ }^{18}$ Appellate Body Report, United States - Final Anti-Dumping Measures on Stainless Steel from Mexico, WT/DS344/AB/R, adopted 20 May 2008, 43.

${ }^{19}$ Bossche, P. V. B. (2009). The Law and Policy of the World Trade Organization, ( ${ }^{\text {nd }}$ ed.). Cambridge, England: Cambridge University Press.

${ }^{20}$ Appellate Body Report, United States - Final Anti-Dumping Measures on Stainless Steel from Mexico, WT/DS344/AB/R, adopted 20 May 2008, 38.

${ }^{21}$ Appellate Body Report, United States - Final Anti-Dumping Measures on Stainless Steel from Mexico, WT/DS344/AB/R, adopted 20 May 2008, 39.

${ }^{22}$ Appellate Body Report, United States - Final Anti-Dumping Measures on Stainless Steel from Mexico, WT/DS344/AB/R, adopted 20 May 2008, 39.
} 
country... ${ }^{, 23}$ However, the introduction of the exported product into the other country has to take place in the ordinary course of trade. This is as mentioned in article 2.1, in reference to the US-Japan Hot-Rolled Steel case. The panel cited no clear definition of the word "ordinary" in the AD agreement: "....However, the Ad does not define the concept of "ordinary course of trade" either in article 2.1 or elsewhere, and establishes no general tests for determining whether sales are made in the ordinary course of trade, or not...". ${ }^{24}$ Thus, in the absence of a definition of "ordinary course", the panel gave the anti-dumping authorities the right to determine if the product made was the same in the home country or not. "...it seems clear to us, and the parties do not that investigating authorities must determine whether sales in the home market are made in the ordinary course trade ..., ${ }^{25}$

There is evidence that a local authority cannot apply provisions in any competition between two or more similar products produced in the same country or within a union of countries. Yet, the domestic industry must be implicated as being effected by a similar imported dumped product:

The domestic industry consists of the domestic producers as a whole of the like products, or of those producers whose collective output constitutes a major preparation of the domestic production of those products. The terms "domestic industry" and domestic producers are also used interchangeable in Article 3.1 and 3.4 of the Agreement. ${ }^{26}$

However, if a portion of the exported products is produced in the country where the dumping case arises, the anti-dumping provision cannot be applied. The reason being, that the source of the products is the same, as mentioned in the footnote for article four: "...producers shall be deemed to be related to exporters or importers only if (a) one of them directly or indirectly controls; or (b) both of them are directly or indirectly controlled by third person; or (c) together they directly or indirectly control a third person...". ${ }^{27}$ This means, the product has be fully exported from another country, and originally from that country or union of countries.

\subsubsection{Market and Competition}

In order to apply anti-dumping rules to influence competition in the marketplace, it is important to have a domestic market in which domestic and imported products can compete. The domestic marketplace should have a good legal trading atmosphere and circumstances favourable to competition. To simplify, the domestic market should employ clear regulations regarding competition, so as to effectively govern operations between domestic and imported products. There should be a good business environment, which supports both foreign and local investors to conduct business fairly with equal access to opportunities. However, the most important point is to exercise strong authority to control the market, by checking the prices and implementation of competition between products. This will maintain the business at a good level of competition and also offer protection. Moreover, it is important for the authorities to maintain strong databases of information relating to competition, both nationally and internationally. This will help to uncover any illegal actions, such dumping, which might have a negative effect on the market, either directly or indirectly.

\subsubsection{Price}

When referring to value, and the definition 'priced less than the normal value', domestic price and export price mentioned as referential concepts in the WTO agreement in regard to dumping action. They are related to mechanisms for uncovering dumping actions in such cases or otherwise. However, price is the most important reported element in anti-dumping cases, as the entire case can be built on the information about price. In Article paragraph 1, it is mentioned that dumping is: “...introduced into the commerce of another country at less than its normal value if the export price of the product exported from one country to another is less than the comparable

\footnotetext{
${ }^{23}$ Agreement on Implementation of Article VI of the General Agreement on Tariffs and Trade 1994 (Anti-Dumping Agreement), 1868 U.N.T.S., Article 2.1.

${ }^{24}$ Panel Report, United States - Anti-Dumping Measures on Certain Hot-Rolled Steel Products from Japan, WT/DS184/R, adopted 23 August 2001, 37- 38 .

${ }^{25}$ Panel Report, United States - Anti-Dumping Measures on Certain Hot-Rolled Steel Products from Japan, WT/DS184/R, adopted 23 August 2001, 38 .

${ }^{26}$ Panel Report, United States - Anti-Dumping Measures on Certain Hot-Rolled Steel Products from Japan, WT/DS184/R, adopted 23 August 2001, 57.

${ }^{27}$ Agreement on Implementation of Article VI of the General Agreement on Tariffs and Trade 1994 (Anti-Dumping Agreement), 1868 U.N.T.S., footnote of Article 4.
} 
price... ${ }^{28}$ However, in the US-Japan Hot-Rolled Steel case, it was mentioned in regard to the establishment of normal value: "...we note that Article 2.1 establishes that normal value is the "comparable price, in the course of trade, for the like product when destined for consumption in the exporting country". 29

Simply put, dumping refers to when an imported similar product is sold at less than its original price in the exporting country. However, this price would also need to be less than the price for a similar product in the importing country. However, arguably, there is no standard for a 'normal' price, as it is changeable according to the circumstances of each individual case. In particular, normal value cannot be based on domestic sales where there are no domestic sales of a product. ${ }^{30}$ Therefore, the normal value of a product is the price at which it is the home market, the market of the product or the export. ${ }^{31}$

However, multiple external factors that can affect the price, whether directly or indirectly. The cost of manufacturing, taxes, government fees, rate of currency exchange, and inflation, all effect the determination of price. Some of these elements are not considered in cases where price is a concern, such as the rate of exchange inflation. On this particular point, there is a case affecting the United States and Korea in regard to unnecessary conversion from the US Dollar to the Korean Won, which allegedly affects the price. ${ }^{32}$

Therefore, for a normal value to be applied four conditions are required: $:^{33}$

1. The sale must be in the ordinary course of trade;

2. It must be a like for like product;

3. It must be destined for consumption in the exporting country; and

4. It must be comparable.

The export price and normal value has to be determined and ordered for the case to be ready for anti-dumping under the these provisions: "Once normal value and export price have been determined in accordance with the provisions of Articles 2.1 through 2.3, Article 2.4 then establishes rules governing the comparison of normal and export price". ${ }^{34}$

In this case, price is an important tool in order to calculate the dumping margin. In other words, without the price of the exports or the price of sale, the dumping margin cannot be calculated as will be seen later in the paper.

\subsubsection{Similarities}

According to $\mathrm{AD}$ Article 2.6, a like product is defined as one that should be, “...identical, i.e. alike in all to product under consideration..., ${ }^{, 35}$ Thus, an imported similar product has to have characteristics that closely resemble the domestic product. It might be confusing to apply (AD) requirements in certain circumstances, as there is no clear identification of like products. This criterion might be clearer if the WTO contracting parties prepared a list of like products to clarify this point to the users of these rules. In this list, it would be easy to similar products without confusion.

A question has been raised that relates to similarities wherein the quality and usage of a product is not mentioned. It might be that two products are similar in all respects and elements, although one is better quality than another. Additionally, in regard to this, the study of the business environment between the two countries (the country in which the products are being dumped and the one which is doing the dumping) is very important in order to discover the similarities between them. Thus, although there are similarities in all respects and the products are

\footnotetext{
${ }^{28}$ Agreement on Implementation of Article VI of the General Agreement on Tariffs and Trade 1994 (Anti-Dumping Agreement), 1868 U.N.T.S., footnote of Article 2.

${ }^{29}$ Panel Report, United States - Anti-Dumping Measures on Certain Hot-Rolled Steel Products from Japan, WT/DS184/R, adopted 23 August 2001, 39.

${ }^{30}$ Vermulst, E. (2008) The WTO Anti-agreement ( $1^{\text {st }}$ ed.) Oxford, England: Oxford University Press.

${ }^{31}$ Lester, S. \& Mercurio, B. with Davies, A. \& Leitner, K. (2008) World Trade Law, Text, Materials and Commentary (1 $1^{\text {st }}$ ed.) Portland, USA. Hart Publishing.

32 Panel Report, United States - Anti-Dumping Measures on Stainless Steel Plate in Coils and Stainless Steel Sheet and Strip from Korea, WT/DS179/R, adopted 1 February 2001.

${ }^{33}$ Lester, S. \& Mercurio, B. with Davies, A. \& Leitner, K. (2008) World Trade Law, Text, Materials and Commentary (1 ${ }^{\text {st }}$ ed.) Portland, USA. Hart Publishing.

${ }^{34}$ Panel Report, United States - Anti-Dumping Measures on Certain Hot-Rolled Steel Products from Japan, WT/DS184/R, adopted 23 August 2001, 40 .

${ }_{35}$ Agreement on Implementation of Article VI of the General Agreement on Tariffs and Trade 1994 (Anti-Dumping Agreement), 1868 U.N.T.S., Article 2.6.
} 
therefore identical (as mentioned in the anti-dumping rules); there may be variations in the uses or quality of the products.

\subsubsection{Injury or Threat}

This section is one of the most complicated in the (AD), and it is hard to prove clearly. Complications arise when calculating the percentage of injury or threat to the domestic industry; for a case, this has to be, “...more than 50 per cent of the total production of the like product produced by that portion of the domestic industry..., 36 the concept of threat to the establishment of domestic industries from an imported similar product is unclear, potentially leading to abuse in the $(\mathrm{AD})$ or misuse due to the difficulties of calculation.

The (AD) does not have a specific definition of injury. However, there are three types of injury under this agreement; as follows:

1. Material injury to an established domestic industry;

2. Threat of material injury to an established domestic industry; and

3. Material retardation of the establishing of a domestic industry. ${ }^{37}$

A central rule when citing this injury is that it has to be a proven material injury to established domestic industries, which extends beyond threat. Thus, the domestic industry has a responsibility to prove injury from the imported product and to present the numbers and figures, to enable the investigating authority to locate injury. However, it may not be easy to prove that injury has resulted in the material retardation of the domestic industry. Many other kinds of retardation can adversely affect established industries, so misdirection could arise.

In Article 3 of the anti-dumping agreement, the means of determination of injury are clarified, "A of injury for purpose of Article VI of GATT 1994 shall be based on positive evidence and involve an objective examination..." ${ }^{38}$ This process must be followed up via investigation, as mentioned in the EC-Bed Linen case: “...They provide for no exceptions, and they include no qualifications. They must be met every investigating authority in every injury determination". "However, this determination of injury must be made based on evidence and objective examination "...investigating authorities must ensure that a "determination of injury" is made on the bases of "positive evidence" and an "objective examination... of the volume and effect of imports are dumped -and to the exclusion of the volume and effect of imports that are not dumped". ${ }^{40}$ Yet, there is no a methodology specified under this article for investigating authorities to apply when calculating the volume of dumped imports "Although paragraph 1 and 2 of Article 3 do not set out a specific methodology that authorities are required to follow when calculating the volume of "dumped imports". 41

The investigative authority has the right to determine the extent or existence of any injury or threat to the industry; this has to be based on fact, as mentioned in the Mexico - Corn Syrup case "...The third sentence of Article 3.7 explicitly recognizes that it is the investigating authorities who make a determination of threat of material injury, and that such determination - by the investigating authorities - "must be based on facts and not merely on allegation, conjecture or remote possibility". ${ }^{42}$ In Thailand, the verdict in the H-Beams case represented a different opinion; the judgment stated that injury cannot be based only on the evidence provided by parties to the investigation. Nevertheless, the investigating authority was found to have the right to search for facts in this case

...in our view, the ordinary meaning of these terms does not suggest that an investigating authority is required to base an injury determination only upon evidence disclosed to, or

\footnotetext{
${ }^{36}$ Agreement on Implementation of Article VI of the General Agreement on Tariffs and Trade 1994 (Anti-Dumping Agreement), 1868 U.N.T.S., Article 5 paragraph 4.

${ }^{37}$ Czako, J. \& Human, J. \& Miranda, J. (2003) A Handbook on Anti-dumping Investigations (1 ${ }^{\text {st }}$ ed.) Cambridge, England : Cambridge University Press.

${ }^{38}$ Agreement on Implementation of Article VI of the General Agreement on Tariffs and Trade 1994 (Anti-Dumping Agreement), 1868 U.N.T.S., Article 3.

39 Appellate Body Report, European Communities - Anti-Dumping Duties on Imports of Cotton-Type Bed Linen from India - Recourse to Article 21.5 of the DSU by India, WT/DS141/AB/RW, adopted 24 April 2003, 42.

${ }^{40}$ Appellate Body Report, European Communities - Anti-Dumping Duties on Imports of Cotton-Type Bed Linen from India - Recourse to Article 21.5 of the DSU by India, WT/DS141/AB/RW, adopted 24 April 2003, 42.

${ }^{41}$ Appellate Body Report, European Communities - Anti-Dumping Duties on Imports of Cotton-Type Bed Linen from India - Recourse to Article 21.5 of the DSU by India, WT/DS141/AB/RW, adopted 24 April 2003, 43.

42 Appellate Body Report, Mexico - Anti-Dumping Investigation of High Fructose Corn Syrup (HFCS) from the United States - Recourse to Article 21.5 of the DSU by the United States, WT/DS132/AB/RW, adopted 21 November 2001, 26.
} 
discernible by, the parties to the investigation. An anti-dumping investigation involves the commercial behaviour of firms, and, under the provisions of the Anti-Dumping Agreement, involves the collection and assessment of both confidential and non-confidential information. $^{43}$

Moreover, the investigating authorities were not able to perform an investigation based on future injury or threat, as this was deemed too difficult to determine, as the Mexico - Corn Syrup judgment emphasised “...In determining the existence of a threat of material injury, the investigating authorities will necessarily have to assumptions relating to "the: occurrence of future events" since such future events "can never be definitively proven by facts". 44

The determination of injury or threat is crucial to proving dumping action affecting a similar domestic product. This determination makes it possible to apply anti-dumping duty to imported similar products, to protect domestic industries from illegal dumping actions.

\subsubsection{Causal Link}

Before applying (AD) rules in any allegation, it is important to establish a link between imported products and injury or threat; i.e. ascertain “...(c) a causal link between the dumped imports and the alleged injury". 45 So, anti-dumping rules do not address the dumping itself; rather they are linked to threat or injury caused to domestic products: "We note, moreover, that Article VI of the GATT 1994 and Anti-Dumping Agreement deal not with dumping per se, but with dumping that causes or threatens to cause material injury to the domestic industry producing a "like" product", ,46

This causal link must be based on all related information in order to guarantee proper examination to clarify a causal link, as mentioned in the US - Stainless Steel case

\section{...Article 3.1 of the Anti-Dumping Agreement stipulates that a determination of injury shall be based on an objective examination of both the volume of the dumped imports and the of the dumped imports on price in the domestic market for like products, and of the consequent impact of the dumped imports on domestic products of such like products. ${ }^{47}$}

However, it is argued herein, that a causal link must take the form of a connection between low price and injury, not between the imported product and injury. It is evident that the cause of injury is not because of the imported product, it is due to the low price of similar imported products. Therefore, if the price was of a normal value, dumping or injury would not apply to a similar domestic product. It is evident in this case that a proper determination must be made between low price and imported product and injury “...A proper determination as whether is dumping or not can only be made on the basis of an examination of the exporter's pricing behaviour reflected in all of its transactions over a period of time...". ${ }^{48}$

It should be stressed that it is permitted to sell imported products on the international market or to compete in a market legally; prohibition centres on selling a product below the normal price, thereby causing injury or threat to other producers. It is apparent, then, that a causal link must be found between low price and injury. Without such a link, such rules would not apply. The causal link is based on information being collected by the investigative authority, as this may or may not show a causal link clearly, as mentioned before.

\footnotetext{
${ }^{43}$ Appellate Body Report, Thailand - Anti-Dumping Duties on Angles, Shapes and Sections of Iron or Non Alloy Steel and H-Beams from Poland, WT/DS122/AB/R, adopted 5 April 2001, 34.

${ }^{44}$ Appellate Body Report, Mexico - Anti-Dumping Investigation of High Fructose Corn Syrup (HFCS) from the United States - Recourse to Article 21.5 of the DSU by the United States, WT/DS132/AB/RW, adopted 21 November 200, 27.

${ }^{45}$ Agreement on Implementation of Article VI of the General Agreement on Tariffs and Trade 1994 (Anti-Dumping Agreement), 1868 U.N.T.S., Article 5 paragraph 2.

${ }^{46}$ Appellate Body Report, United States - Final Anti-Dumping Measures on Stainless Steel from Mexico, WT/DS344/AB/R, adopted 20 May 2008, 41.

${ }^{47}$ Appellate Body Report, United States - Final Anti-Dumping Measures on Stainless Steel from Mexico, WT/DS344/AB/R, adopted 20 May 2008, 41.

${ }^{48}$ Appellate Body Report, United States - Final Anti-Dumping Measures on Stainless Steel from Mexico, WT/DS344/AB/R, adopted 20 May 2008, 44.
} 


\subsection{Main Steps of the Dumping Cases}

Dumping cases, at a national level, has to be initiated by a complaint from a domestic similar industry; this should be more than $50 \%$ of the entire internal producer's capacity in the market. However, the government authority can start the process on behalf of domestic industry, and a percentage of that domestic industry will

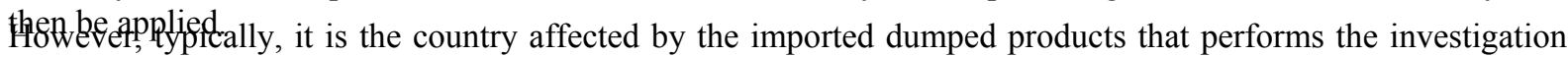
and makes the decision to apply anti-dumping duty. It would therefore be fairer if the anti-dumping authority could check the information being collected from both disputants, and then transfer the case to a domestic commercial court. This will be discussed in detail further on in this research.

During the investigation, all parties have a right to defend their interests under anti-dumping agreements: "The panel justified this finding by noting that it would provide interested parties in an anti-dumping investigation a "meaningful opportunity to defend their interests" during the investigation..." "Throughout the anti-dumping investigation all interested parties shall have a full opportunity for the defend of their interests" ${ }^{50}$ Thus, anti-dumping investigators must perform three different steps: (1) the initiation of the investigation, (2) a preliminary and final investigation; and (3) observing changes in circumstances requiring a review of duty.

In terms of initiation, the local authority should start the investigation once all similar domestic producers have submitted their applications; they will then send a questionnaire to all parties. On a practical point, the authorities must collect all the information related to the investigation, in order to check for alleged dumping and injury: authorities shall examine the accuracy and adequacy of the evidence provided in the application to determine whether there is sufficient evidence to justify the initiation of an investigation". ${ }^{51}$ Authorities must check the dumping margin at this stage. If the dumping margin was de minimis or negligible, the case against the imported product would then be terminated. This process should not take more than 60 days, in order to allow the country to adjust its pricing, "...the authorities shall allow exporters at least 60 days to have adjusted their export prices". ${ }^{2}$

After the process of the initiation, the authorities have the right to take some measures as discussed in the case of US-Hot-Rolled Steel:

Article 10.7 of the AD Agreement provides that certain preliminary measures may be taken "after initiation". This implies that at the time of the critical circumstance determination, authority has already determined, under Article 5.3, that the petition contained sufficient information of dumping and injury, and causal link to justify the initiation of the investigation. ${ }^{53}$

However, the period of time between the preliminary and final determination has to follow the AD rule on this point "...normally within 12 months and in no case more than 18 months..." $" 54$ At this point, the investigating authority would apply the anti-dumping duty according to the available facts and information.

Usually a final determination takes no more than 5 years: “...anti-dumping duty shall be terminated on a date not later than five years from its imposition... " $" 55$ However, without any change in the circumstances or case facts, authorities can extend the effect of anti-dumping duty in excess of 5 years. If there is any kind of change in the information being given, especially the price, the review will take place and might terminate anti-dumping duty

\footnotetext{
49 Appellate Body Report, Thailand - Anti-Dumping Duties on Angles, Shapes and Sections of Iron or Non Alloy Steel and H-Beams from Poland, WT/DS122/AB/R, adopted 5 April 2001,30.

${ }^{50}$ Agreement on Implementation of Article VI of the General Agreement on Tariffs and Trade 1994 (Anti-Dumping Agreement), 1868 U.N.T.S., Article 6.2.

${ }^{51}$ Agreement on Implementation of Article VI of the General Agreement on Tariffs and Trade 1994 (Anti-Dumping Agreement), 1868 U.N.T.S., Article 5 paragraph 3.

52 Agreement on Implementation of Article VI of the General Agreement on Tariffs and Trade 1994 (Anti-Dumping Agreement), 1868 U.N.T.S., Article 2 paragraph 4.1 .

${ }_{53}$ Panel Report, United States - Anti-Dumping Measures on Certain Hot-Rolled Steel Products from Japan, WT/DS184/R, adopted 23 August 2001, 48 .

${ }^{54}$ Agreement on Implementation of Article VI of the General Agreement on Tariffs and Trade 1994 (Anti-Dumping Agreement), 1868 U.N.T.S., Article 9 paragraph 3.1.

${ }_{55}$ Agreement on Implementation of Article VI of the General Agreement on Tariffs and Trade 1994 (Anti-Dumping Agreement), 1868 U.N.T.S., Article 11 paragraph 3.
} 
reduce it. However, Article 11 allows for a review of anti-dumping duty upon request from any of the involved parties. $^{56}$

\subsection{Termination or Suspension of the Anti-Dumping Process}

Cases of anti-dumping can be rejected, terminated or suspended according to three cases:

1. If a domestic industry of similar product in an importing country has withdrawn its case, it will be immediately terminated, as there is no allegation from domestic industry.

2. If the domestic industry for a similar product could not prove a dumping action, implicating the imported product, or has not fulfilled all the conditions of the anti-dumping provisions, in order to continue the anti-dumping process.

3. If the margin of dumping is de minimis, which means the margin is less than 2 per cent of the export price: "...there shall be immediate termination in cases where the authorities determine that the margin of dumping is de minimis". 57

4. If the volume of dumped imports from a particular country is less than 3 per cent of imports, it will be considered negligible: “...the volume of dumped imports from a particular country is found to account for less than 3 per cent of imports of the like product in the importing Member". ${ }^{58}$

5. Price undertakings, which are implied when the importing country voluntarily undertakes to revise its price or to cease exports at the dumped price:

proceedings may be suspended or terminated without the imposition of provisional

measures or anti-dumping duties upon receipt of satisfactory voluntary undertakings

from any exporter to revise its price or to cease exports to the area in question at dumped prices so that the authorities are satisfied that the injurious effect of the dumping is eliminated. ${ }^{59}$

\subsection{Legal Understanding of Anti-Dumping Duty}

This point is best addressed in three sections: (1) the legal characterisation of the charge or duty, fine, tax, or tariff; (2) how anti-dumping duty is calculated; (3) the beneficiary of the charge.

\subsubsection{Legal Characterization of Anti-Dumping Duty}

The WTO aims to support free trade between members without any obstacles, in the form of rules, tariffs As this agreement has reduced tariffs to a minimum between members, benefits will be eroded in cases of when the WTO agreement is enforced; as a decrease in variation is in place from the outset. The legal characterisation of anti-dumping duty in this research can be considered as a tariff, but applied with conditions in the case of a dumping action; such action is illegal according to this agreement. In addition, tariffs and anti-dumping duties are important as means to protect domestic industries: "Tariffs and anti-dumping duties are two important tools that can protect industries from foreign competition and generate revenue to countries initiating them ". ${ }^{60}$ As previously mentioned, anti-dumping duty is applied to protect domestic producers from imported products: "in other words, an anti-dumping duty serves the purpose of industry protection". 61 Thus, tariffs can be applied for various purposes, such as promoting income levels throughout the nation: "A tariff is typically designed to maximise either domestic revenue or domestic welfare". ${ }^{2}$ However, a tariff may also be imposed to protect domestic industries and products by creating a price differential that leads customers to prefer the domestic products.

\footnotetext{
${ }^{56}$ Agreement on Implementation of Article VI of the General Agreement on Tariffs and Trade 1994 (Anti-Dumping Agreement), 1868 U.N.T.S., Article 11 .

${ }^{57}$ Agreement on Implementation of Article VI of the General Agreement on Tariffs and Trade 1994 (Anti-Dumping Agreement), 1868 U.N.T.S., Article 5 paragraph 8.

${ }_{58}$ Agreement on Implementation of Article VI of the General Agreement on Tariffs and Trade 1994 (Anti-Dumping Agreement), 1868 U.N.T.S., Article 5 Paragraph 8.

${ }^{59}$ Agreement on Implementation of Article VI of the General Agreement on Tariffs and Trade 1994 (Anti-Dumping Agreement), 1868 U.N.T.S., Article 8.

${ }^{60}$ Dinlersoz, E. \& Dogan, C. (2010) Tariffs versus anti-dumping duties. Journal of International Review of Economics and Finance, 19(3), 436-451. http://dx.doi.org/10.1016/j.iref.2009.10.007

${ }^{61}$ Dinlersoz, E. \& Dogan, C. (2010) Tariffs versus anti-dumping duties. Journal of International Review of Economics and Finance, 19(3), 436-451. http://dx.doi.org/10.1016/j.iref.2009.10.007

${ }^{62}$ Dinlersoz, E. \& Dogan, C. (2010) Tariffs versus anti-dumping duties. Journal of International Review of Economics and Finance, 19(3), 436-451. http://dx.doi.org/10.1016/j.iref.2009.10.007
} 


\subsubsection{Calculating the Anti-Dumping Duty}

Anti-dumping duty cannot be imposed before all dumping conditions have been fulfilled. Dumping margin, injury or threat and finally any causal link must be assessed before applying anti-dumping duty; as in the EC-Bed Linen case:

Members have the right to impose and collect anti-dumping duties only after the completion of an investigation in which it has been established that the requirement of dumping, injury, and causation "have been fulfilled". In other words, the right to impose anti-dumping duty under Article 9 is a consequence of the prior determination of the existence of dumping margins, injury, and a causal link. ${ }^{63}$

The aim when applying anti-dumping duty is to impede unfair competition by the dumping of similar imported products, which is injurious or threatening to similar domestic products: "...the very purpose of an anti-dumping duty is to counteract the injury caused or threatened to be caused by "dumped imports" to the domestic industry..." ${ }^{\prime 64}$ The aim of anti-dumping processes is to target three points, as mentioned in articles 2.4.2 and the EC - Bed Linen case "This provision allows Members, in structuring their anti-dumping investigations, to address three kinds of "targeted" dumping, namely dumping that is targeted on certain purchasers, targeted to certain regions, or targeted to certain time periods". ${ }^{65}$ Calculating anti-dumping duty simply refers to the between the price when selling a product from abroad onto the domestic market and the selling price for this product in its home country, which is lower.

The dumping margin has been defined in the Appellate Body Report US-Mexico Stainless Steel as: "...the difference between the "export price" and the "normal value" (that is, "the domestic price" of the like product in the exporting country) determined in accordance with Article VI:2 further clarifies that the "margin of dumping" is in respect of the dumped "product"..." ${ }^{66}$ However, it has been confirmed that dumping and the margins of dumping are both concepts related to export matters "Other provision of the Anti-Dumping also confirm that "dumping" and margin of dumping" are exporter - specific concepts" ${ }^{67}$ Arguably, the Appellate Body was not in agreement with the panel's report in regard to its interpretation of article 9.3: "We do not agree that the Appellate Body's interpretation of Article 9.3 would favour "importers with high margins of dumping...at the expense of importers who do not dump or who dump at a lower margin", as the Panel suggest". ${ }^{8}$ The right interpretation is that "...an "offset" is provided for the so-called "non-dumped" transactions" ${ }^{69}$ However, the anti-dumping duty should not exceed the margin: "The amount of the duty shall not exceed the margin of dumping...,"70

However, under article 2.4.2 of the anti-dumping agreement, there are three methodologies for calculating the margin of dumping as mentioned in the US - Softwood Lumber V: "This provision establishes three methodologies that investigation authorities may use to calculate the "margins of dumping during the investigation phase". ${ }^{71}$ They are as follows, weighted average-to-weighted average, transaction-to-transaction

\footnotetext{
${ }^{63}$ Appellate Body Report, European Communities - Anti-Dumping Duties on Imports of Cotton-Type Bed Linen from India - Recourse to Article 21.5 of the DSU by India, WT/DS141/AB/RW, adopted 24 April 2003, 48.

${ }^{64}$ Appellate Body Report, United States - Final Anti-Dumping Measures on Stainless Steel from Mexico, WT/DS344/AB/R, adopted 20 May 2008, 45.

${ }_{55}$ Appellate Body Report, European Communities - Anti-Dumping Duties on Imports of Cotton-Type Bed Linen from India, WT/DS141/AB/R, adopted 12 March 2001, DSR 2001:V, 2049, 19.

${ }^{66}$ Appellate Body Report, United States - Final Anti-Dumping Measures on Stainless Steel from Mexico, WT/DS344/AB/R, adopted 20 May 2008, 39.

${ }^{67}$ Appellate Body Report, United States - Final Anti-Dumping Measures on Stainless Steel from Mexico, WT/DS344/AB/R, adopted 20 May 2008, 40.

${ }^{68}$ Appellate Body Report, United States - Final Anti-Dumping Measures on Stainless Steel from Mexico, WT/DS344/AB/R, adopted 20 May 2008, 50.

${ }^{69}$ Appellate Body Report, United States - Final Anti-Dumping Measures on Stainless Steel from Mexico, WT/DS344/AB/R, adopted 20 May 2008, 50.

${ }^{70}$ Agreement on Implementation of Article VI of the General Agreement on Tariffs and Trade 1994 (Anti-Dumping Agreement), 1868 U.N.T.S., Article 9 paragraph 3.

${ }^{71}$ Appellate Body Report, United States - Final Dumping Determination on Softwood Lumber from Canada - Recourse to Article 21.5 of the DSU by Canada, WT/DS264/AB/RW, adopted 1 September 2006, 34 .
} 
and finally weighted average-to-transaction. ${ }^{72}$ The first two methodologies used by authorities are normally introduced to establish the dumping margin. The final methodology is used only under two conditions; i.e. (1) if the authorities find the pattern of the export price, and (2) where there is a clear explanation of why it is not possible to use the other first two methodologies.

These two methodologies "shall normally" be used by investigating authorities to establish margins of dumping. The second sentence of Article 2.4.2 sets out a third methodology (weighted average-to-transaction), which involves an asymmetrical comparison and may be used only in exceptional circumstances. It may be used only if the following two conditions are met: (i) "the authorities find a pattern of export prices which differ significantly among different purchasers, regions or time periods"; and (ii) "an explanation is provided as to why such differences cannot be taken into account appropriately by the use of a weighted average-to-weighted average or transaction-to-transaction comparison". ${ }^{73}$

However, in the same case, it was agreed that the investigation authorities would use multiple averaging, under weighted average - to - weighted average comparison methodology ${ }^{74}$ Yet, the idea differs in cases where the investigation authorities' choose to apply multiple comparisons ".... [i]f an investigation authorities has chosen to undertake multiple comparison, the investigation authority necessarily has to take into account the result of all those comparisons, in order to establish margins of dumping for the product as a whole under Article 2.4.2."75

Moreover, in the US - Softwood Lumber V case, the Appellate Body mentioned interpretation of zeroing, which "Our interpretation that zeroing is not permissible when calculating margins of dumping by comparing normal value and export prices on a transaction-to-transaction basis is consistent with other provisions of the Anti-Dumping Agreement as well..." ${ }^{, 76}$ The zeroing concept applied in the US - Zeroing It - has also been in Korea "Thus, as we understand it, by zeroing, the investigating authority treats as zero the difference between the weighted average normal value and the weighted average export price in the case of those sub-groups where the weighted average normal value is less than the weighted average export price" "77

\section{Anti-Dumping under Islamic Law}

For the early Muslims trade played a very important role in their lives. In regard to this, God says in the Holy Quran, of the trade of Quraysh Tribe between Syria and Yemen "For the accustomed security of the Quraysh. Their accustomed security [in] the caravan of winter and summer". ${ }^{78}$ Even, when the Prophet Mohammed emigrated from Mecca to Medina, the first priority was to build his holy mosque and then open a market for people to trade in. ${ }^{79}$

However, Islamic law has the advantage of striking a balance between individuals' and society's interests “...Islam has raised a balance between the interest of individuals and society... ",80 Thus, economics under Islamic law differed from that in capitalist or socialist economic systems inside the market, as their aims were entirely different from the Islamic economic system. Islamic law stressed and encouraged people to have embark on trade and engage competitively; as God says in the Holy Quran:

$O$ mankind, eat from whatever is on earth [that is] lawful and good and do not follow the footsteps of Satan. Indeed, he is to you a clear enemy" "81 Also, God says in the Holy Quran " $O$

\footnotetext{
72 Appellate Body Report, United States - Final Dumping Determination on Softwood Lumber from Canada - Recourse to Article 21.5 of the DSU by Canada, WT/DS264/AB/RW, adopted 1 September 2006, 34 .

${ }^{73}$ Appellate Body Report, United States - Final Dumping Determination on Softwood Lumber from Canada - Recourse to Article 21.5 of the DSU by Canada, WT/DS264/AB/RW, adopted 1 September 2006, 34.

${ }^{74}$ Appellate Body Report, United States - Final Dumping Determination on Softwood Lumber from Canada - Recourse to Article 21.5 of the DSU by Canada, WT/DS264/AB/RW, adopted 1 September 2006, 36 .

${ }^{75}$ Appellate Body Report, United States - Final Dumping Determination on Softwood Lumber from Canada - Recourse to Article 21.5 of the DSU by Canada, WT/DS264/AB/RW, adopted 1 September 2006, 35.

${ }^{76}$ Appellate Body Report, United States - Final Dumping Determination on Softwood Lumber from Canada - Recourse to Article 21.5 of the DSU by Canada, WT/DS264/AB/RW, adopted 1 September 2006, 43.

${ }^{77}$ Panel Report, United States - Use of Zeroing in Anti-Dumping Measures Involving Products from Korea, WT/DS402/R, adopted 24 February 2011, 13.

78 The Holy Quran [106: 1 to 4].

${ }^{79}$ Ali, M. A. H. (2009) Dumping as One of the Unfair Competition ( $1^{\text {st }}$ ed.) Cairo, Egypt : Dar Alnahda Alarabia.

${ }^{80}$ Ali, M. A. H. (2009) Dumping as One of the Unfair Competition (1 $1^{\text {st }}$ ed.) Cairo, Egypt : Dar Alnahda Alarabia. (Researcher's translation).

${ }^{81}$ The Holy Quran [2:168].
} 
you who have believed, do not consume one another's wealth unjustly but only [in lawful] business by mutual consent. And do not kill yourselves [or one another]. Indeed, Allah is to you ever Merciful. ${ }^{82}$

Under Islamic law, traders were taught how to act in the market, in order to further flexibility and trust. Islamic law prohibited any form of fraud or deception in the trade between people: "Muslims are brothers and it is not permissible if they sold any things with any flaw and not shown to the payer". ${ }^{83}$ However, Islamic law also prohibited paying someone for something that is being undersold; Prophet Mohammed said, "A man is not to undersell his brother, nor is he to try to out haggle his brother". ${ }^{84}$ Thus, a trader must not be involved in any of the prohibited trade treatment or sale of products under Islamic law. ${ }^{85}$

The rules of competition under Islamic law are the same, whether this affects the domestic or international Islamic law encouraged the notion of competition for good deeds, even between traders. God states in the Holy Qur'an: "...So for this let the competitors compete". ${ }^{86}$ Therefore, it is not acceptable that any kind of harm should come to the market or products due to unfair treatment of the people. God also says in the Holy Qur'an "And $O$ people, give full measure and weight in justice and do not deprive the people of their due and do not commit abuse on the earth, spreading corruption". ${ }^{87}$ On this point, Prophet Mohammed stated, "There should be neither harming nor reciprocating harm " ${ }^{\prime 8}$ as a general principle for any treatment. The last evidence from the Holy Qur'an and the traditions of Prophet Mohammed shows the general rules that should be followed when dealing with people inside the market. However, Muslims believe that on the Day of Judgment, there will be a penalty imposed on people who do not follow these rules.

First we consider dumping, which is not a term used in Islamic law. However, the meaning of dumping, that is selling products below their normal value in the importing market, it understood and legislated in Islamic law. Within this context the rule of individual initiative that exists in Islamic law is of relevance. This refers to each person's responsibility for his own behaviour, in particular, that such behaviour must follow the rules of Islamic law in some circumstances in regard to good deeds and faith.

Islamic law prohibits the authority from setting a fixed price inside the market for any products, as it respects the principle of a free market without restrictions. ${ }^{89}$ However, free pricing has to be based on the real cost of the product, including also a profit margin. This dates to when prices became excessive during the time of the Prophet Mohammed; he refused to set a price:

Prices became excessive during the time of the Messenger of Allah, so they said: 'O Messenger of Allah! Set prices for us!' So he said: 'Indeed Allah is Al-Musa'ir, Al-Qabid, Al-Basir, Ar-Razzaq. And I am hopeful that I meet my Lord and none of you are seeking (recompense from) me for an injustice involving blood or wealth" 90 Also, Prophet Mohammed said, "Whoever interferes with the prices among the Muslims to cause those prices to increase, Allah has the right to seat him in a severe fire on the Day of Judgement. ",91 So, Ibn Alqayyim" said "for fixing the price, it can be injustice and prohibited and can be fair and allowed. For that, if the fixing price will harm people and forcing them to sell their products without their interested price or prevent them with what God has permitted to them,

\footnotetext{
82 The Holy Quran [4:29].

${ }^{83}$ Ali, M. A. H. (2009) Dumping as One of the Unfair Competition ( $1^{\text {st }}$ ed.) Cairo, Egypt : Dar Alnahda Alarabia. (Researcher's translation).

${ }^{84}$ Sunan Ibn Majah, Vol. 3, Book 12, Hadith 2172.

${ }^{85}$ There are many types of prohibited contracts and products under the Islamic law. As an example of the prohibited contracts such a contract including an interest as God says “...But Allah has permitted trade and has forbidden interest...” Quran [2:275]. Also for the prohibited products, such selling alcohol and others as God says " $O$ you who have believed, indeed, intoxicants, gambling, [sacrificing on] stone alters [to other than Allah ], and divining arrows are but defilement from the work of Satan, so avoid it that you may be successful" Quran [5:90].

${ }^{86}$ Holy Quran [83:26].

${ }^{87}$ Holy Quran [11: 85].

${ }^{88}$ Sunan Ibn Majah, Vol. 3, Book 13, Hadith 2341.

${ }^{89}$ Enaya, G. (1992) The Control Regulation of the Economic in the Islamic Market (1 $1^{\text {st }}$ ed.) Beirut, Lebanon: Dar Alnafa'es.

${ }^{90}$ Jami' at-Tirmidhi,Vol.3, Book 12, Hadith 1314.

${ }^{91}$ Musnad Ahmad, Mustadrak al-Hakim [2/12-13].

${ }_{92}$ Ibn Alqayyim is Mohammed ibn Abo Bakr ibn Ayob. He is one of the late Islamic scholars, from the Ahmed ibn Hambil Sunni school of thought.
} 
then it is prohibited. If the fixing price will have a fair between people as preventing them for not doing what God has not permitted, then it is allowed... ${ }^{93}$

However, some religious scholars agree to have a fixed price for an item in circumstances where there are urgent economic issues or potential for huge harm to the market or consumers.

Second, it is important for the sale price to be set at a normal value for similar products in the market, rather than below it. Regarding this point, Umer ibn Al-khattab, ${ }^{94}$ when walking into the market found a trader selling below the normal price for similar products. Umer said to him: "Either increase the price or leave our market".95 Moreover, Imam Malik ${ }^{96}$ said: "If there is a man who wants to destroy the market by selling below the normal price, it is better to tell him: either raise your price to the normal or leave the market" ${ }^{97}$ Yet, Imam Alshafi ${ }^{98}$ expresses a different opinion, citing Umer ibn Al-khattab's remorse stating, " what I said was not a or a court order, but I wanted only the good for people, so, whatever and whenever sell your product",99 So, Imam Alshafi agrees that the man's aim was not to harm the market, it was only to sell his product. ${ }^{100}$ However, the man at that time wanted to damage the market, Imam Alshafi opinion would have led to a different result.

In this paper, we note that Umer ibn Al-khattab agreed to keep the market safe, protecting other sellers from harm. Yet, Imam Malik and Imam Alshafi, both agreed regarding this idea of Umer; thus, it can be seen that selling a product below the market price, if it will harm the market, is prohibited.

Third, there is a rule prohibiting monopoly, which sometimes also has been found to result from dumping. Mohammed said, "No one withholds goods till their price rises but a sinner". ${ }^{101}$ The monopolist and price manipulation suffer the penalty of hell fire on the Day of Judgment if that person continues with this action. This evidence stressed the need for free trade between people, based on principles of fair competition without doing harm, whether to the market, the consumer or the trader.

However, a question can be raised here in relation to the penalty for dumping action under Islamic law. There are many actions that can be taken against dumping in Islamic law. First, the trader may be asked to raise his price to a normal value, as in the story of Umer ibn Al-khattab. This action helps to protect the market from harm proceeding from the dumping action. Second, the authority can fix the price if harm or injury is anticipated as a result of the act of dumping, and the majority of Muslims scholars concur with this approach. Third, under Islamic law it is possible to impose additional penalties on the traders if they are in a position to harm the market by dumping. One of these actions was mentioned in the story of Umer ibn Al-khattab; he asked a trader to remove his product from the market. In addition, under Islamic law, a leader can ask a trader, who his selling his product below normal price, to pay compensation for any injury proceeding from this action.

Moreover, Islamic law confirms there is a special system in place to control the market, as defined under the concept of Hisbah. God says "And let there be [arising] from you a nation inviting to [all that is] good, enjoining what is right and forbidding what is wrong, and those will be the successful". 102 Prophet Mohammed said "Whosoever of you sees an evil, let him change it with his hand; and if he is not able to do so, then [let him change it] with his tongue; and if he is not able to do so, then with his heart - and that is the weakest of faith". ${ }^{03}$ These two examples provide the basis for the authority to control the market and check the implementation of free trade between people without incurring harm or injury. All Muslim leaders have used this principle, especially in reference to market and trade.

Thus, it is apparent that Islamic law has prohibited dumping in a variety of ways, and that Islamic leaders have sought to avoid fixed prices on the market. This has been achieved without the control of Islamic law and

\footnotetext{
${ }_{93}$ Mohammed, Y. K. M. (1998) Faqh Economic of the Market-Private Activity (1 ${ }^{\text {st }}$ ed.) Cairo, Egypt : Dar Alnasher. (Researcher's translation).

${ }^{94}$ Umer ibn Alkhattab is the second leader of the early Islamic nation after Prophet Mohammed and Abo Bakr.

${ }^{95}$ Muwatta Malik, Book 31, Hadith 57.

${ }^{96}$ Imam Malik is Malik ibn Anas ibn Malik. He is the second Islamic scholar in the Sunni Islamic school of thought.

97 Shehata, M. A. (2007) International Trade in the Light of Islamic Law and GATT - A comparative study (1 $1^{\text {st }}$ ed.) Alexandria, Egypt: Dar Alfikr Algamie. (Researcher's translation).

${ }^{98}$ Imam Alshafi is Mohammed ibn Edrees Alshafi. He is the third Islamic scholar in the Sunni Islamic school of thought and a very important scholar.

99 Ali, M. A. H. (2009) Dumping as One of the Unfair Competition (1 $1^{\text {st }}$ ed.) Cairo, Egypt: Dar Alnahda Alarabia. (Researcher's translation).

${ }^{100}$ Ali, M. A. H. (2009) Dumping as One of the Unfair Competition ( $1^{\text {st }}$ ed.) Cairo, Egypt: Dar Alnahda Alarabia. (Researcher's translation).

${ }^{101}$ Sunan Abi Dawud, Book 23, Hadith 3440.

102 Holy Quran [3:104].

10340 Hadith Nawawi, Hadith 34.
} 
harm to other traders inside the market. This has given traders the opportunity to compete fairly, as the "anti-dumping" authority, i.e. the Islamic leader, controlled the market with strict rules. It can therefore be that historically the first anti-dumping rule was applied under Islamic law, not Canadian law as suggested earlier.

\section{Anti-dumping under Saudi Arabian Domestic Law}

As a consequence of Saudi Arabia joining the WTO agreement, Royal Decree number M/30 dated 13 June 2006 was issued to accept new rules with regard to anti-dumping and countervailing measures. ${ }^{104}$ This rule was by the Cooperation Council for the Arab States of the Golf (GCC) to address these legal issues as a union. A Decree, issued on 28 January 2013, adopted the amendment and implemented ${ }^{105}$ a version of this rule in order to be in compliance with the WTO agreement.

The rule issued in 2006 contained only 17 articles, offering a general framework for how the (GCC) countries could deal with relevant cases. This rule established three committees: a Ministerial Committee, a Standing Committee and a Technical Committee; each with a unique role in handling types of cases. This research will suggest there is no need for these committees. The (GCC) countries could take advantage of the (EU) countries rules as an example and counter anti-dumping cases as a conglomerate. At present, the three committees could act as an obstacle to dealing with these legal issues, which represent a bureaucratic process. The implementation of this rule includes 97 articles covering all aspects in regard to anti-dumping measures.

Thus, when an act of dumping in any non-GCC products happens affecting countries with similar products, the (GCC) countries must work together to fight this by filing a case, whether using representatives of $50 \%$ of similar products or through authorities in countries like the Chambers of Commerce or the Ministry of Commerce. In this way they act together, like the (EU) countries, with regard to anti-dumping, thereby strengthening their domestic industries leading them to develop and improve these industries.

However, when (GCC) products face legal action targeting anti-dumping against a (GCC) nation, that country deal with the matter separately and without support from the (GCC), as occurred in the case against the Saudi Omani petrochemical products. ${ }^{106}$ Saudi Arabia has established a negotiation committee, headed by His Royal Highness Prince Abdul-Aziz bin Salman, who was a Deputy of the Ministry of Petroleum and Mineral Resources for the Petroleum Sector, dealing with these cases abroad. This committee successfully concluded anti-dumping legal actions against Saudi petrochemical products, but without coordination or cooperation with the (GCC) countries.

To clarify, in the case above; which was made against a Saudi, Omani and Singapore petrochemical products, it was terminated after the committee intervened with the Indian government. However, this case continued in Oman, despite it being one of the (GCC) countries. This clearly shows that the committee had not been in coordination with other (GCC) countries.

On another point, there was a department in the Saudi Ministry of Commerce which examined anti-dumping authorities in Saudi Arabia, and which had more of a role with regard to cases like this, whether inside Saudi Arabia or outside. However, this department did not intervene with the committee officially or even work closely with the (GCC) committee in order to protect the (GCC) industries. Thus, it is apparent that there are three bodies that deal with such cases in Saudi Arabia: the committee headed by HRH Prince Abdul-Aziz, the department under the Ministry of Commerce, and finally the umbrella body of the (GCC) council itself. This can make the situation more confusing when any sector or industry seeks to deal with such cases; there should also be more coordination and cooperation within the (GCC) council, as all (GCC) countries have agreed to handle Fuch legal issues together. dumping case affecting one (GCC) member in another (GCC) member's country, the question arises: will anti-dumping rules be applied? As these countries deal with each other as a single conglomerate, anti-dumping law cannot be applied by a single member against another. However, this research found that competition law will be applicable in such cases. Nonetheless, anti-dumping law for (GCC) countries does not mention or cover this point in reference to (GCC) countries.

In addition, when Saudi Arabia signed the (WTO) agreement, it was reserved about many things, one of which its subsidy programme. ${ }^{107}$ Until now, Saudi Arabia has been offering subsidies in many areas, such as electricity

\footnotetext{
104 The Bureau of Experts at the Saudi Council of Ministries.

105 It was adopted by the GCC Summit No. 31 in Abu Dhabi on 7 December 2010. See the official GCC website www.gcc-sg.org

106 Indian case number 14/5/2009-DGAD. See this case in the Indian Ministry of Commerce http:/www.commerce.nic.in/

107 Aljarallah, A. M. (2010) Analysing the Impact of the World Trade Organisation (WTO) on the Sustainability of Competitiveness of the Petrochemical Industry in Saudi Arabia (Unpublished Doctoral dissertation). Durham University, Durham, England.
} 
and gas. ${ }^{108}$ These programmes have had a direct effect on competition, both inside Saudi Arabia and outside, where the products being exported.

\section{Compatibility between WTO Law, Saudi Arabia's Anti-Dumping Law and Islamic Law}

The European Union has received complaints regarding the compatibility of the US Anti-Dumping Act of 1916 and the WTO agreement: "We note that EC contests the compatibility of the 1916 Act as such - not of particular instances of application - with certain provisions of the WTO Agreement..." ${ }^{\prime 109}$ In this particular case, the panel recommended the US to alter the anti-dumping Act 1916 to make it compatible with the WTO agreement "We therefore recommend that the DSB request the United States to bring the 1916 Act into conformity with its obligations under the WTO Agreement". ${ }^{110}$ This request was based on public international law that requires nations to fulfil all the obligations of any agreement signed by that nation. ${ }^{11}$

In the previous example, domestic anti-dumping law had to be compatible with anti-dumping law under the WTO agreement. This was an obligation imposed on states, as they were signatories to the agreement. Therefore, the following section explores whether Islamic law and Saudi domestic law, in regard to anti-dumping, is compatible with the WTO agreement.

\subsection{Competition between Products and Normal Value}

In the earlier sections in of this paper and in reference to anti-dumping law, dumping as defined under article VI of the GATT “...introduced into the commerce of another country at less than normal value of the products...". ${ }^{112}$ There is no difference between Islamic law, Saudi Arabian domestic law and the WTO agreement in this aspect. Islamic law has stressed the need for fair competition between products in the marketplace. Yet, Umer ibn Al-khattab asked that this product be removed from the market if prices were not increased on similar products. In addition, if this action leads to harm and injury from other products under Islamic law, it will prohibit Muslim leaders from implement penalties in regard to these products. This article is therefore also compatible with domestic Saudi anti-dumping law.

There is a slight variation in regard to determining normative value and anti-dumping duty under Islamic law than under the WTO agreement; nevertheless, it is acceptable to adapt this from the WTO agreement, as the Saudi leader has the right to adopt laws if they do not conflict with Islamic law. The idea of anti-dumping under Islamic law is simpler than that under under the WTO agreement. However, both Islamic law and the WTO agreement agree in regard to the need for fair competition in the marketplace between products and Saudi anti-dumping domestic law.

\subsection{Fixing the Price of Such a Products}

As mentioned above, the Prophet Mohammed refused to fix prices where this might limit competition in the marketplace negatively; this also affected the application of the WTO agreement in regard to anti-dumping laws, and to having fair competition between products. The fixing price would not be fair either to the trader or the trade process. In this case, Islamic law has placed the general rules of competition between traders inside a market as protected from any interference on price. This point is entirely appropriate and supportive of the main theory behind anti-dumping. However, if there is harm to the market and some scholar understands of Islamic law, the leader may then interfere in the market and fix the price. However, no one has the right to interfere in the market on pricing under anti-dumping rules expressed in the WTO agreement.

\subsection{The Injury to Other Products}

Under Islamic law, it is important to address injury in any part of the trade process. For we can refer to the action of Umer ibn Alkhattab (see above) when he returned to the man's house and asking him to sell his product wherever he wished, as his purpose was not to damage the market. For this reason, Umer allowed him to sell his product anywhere. In addition, if there is an injury caused by dumping action in a market, under Islamic law, it is prohibited.

\footnotetext{
108 Trade Policy Review, prepared by the Secretariat of the World Trade Organization, Report no. WT/TPR/256, 21 December $2011,40$.

109 Panel Report, United States - Anti-Dumping Act of 1916, Complaint by the European Communities, WT/DS136/R, adopted 26 September 2000, 117.

${ }^{110}$ Panel Report, United States - Anti-Dumping Act of 1916, Complaint by the European Communities, WT/DS136/R, adopted 26 September 2000, 166.

111 Panel Report, United States - Anti-Dumping Act of 1916, Complaint by the European Communities, WT/DS136/R, adopted 26 September $2000,119$.

112 Agreement on Implementation of Article VI of the General Agreement on Tariffs and Trade 1994 (Anti-Dumping Agreement), 1868 U.N.T.S., 201.
} 
This principle is applicable to the WTO's anti-dumping rules. Moreover, if there is any harm that would be caused by a subsidising programme, it would then be prohibited under Islamic law, as clarified in this paper. The idea of no injury to the market under the Islamic law is a main concept and pillar of the trading mechanism.

\section{Compatibility between Islamic Law and Modern Laws}

Islamic law has the flexibility of openness to adaptation to modern laws, if there is no any such conflict between them and the general principles of Islamic law. If modern laws do not include any prohibition contracts or products, they will be acceptable. For that reason, the anti-dumping law under the WTO agreement can be adopted under Islamic law while only slightly adapting them in regard price fixing. Moreover, Islamic law typically prefers to adapt as society changes, which is a key advantage when using Islamic law.

\section{Conclusion}

This paper found the compatibility between the WTO agreement, Islamic law and Saudi domestic law has been highlighted in regard to anti-dumping. As Saudi Arabia relies on Islamic law for its basic regulations, there are few barriers to the adoption of laws from the WTO agreement. However, other legal systems that use Islamic law as a basis for regulations can perform the same steps without difficulties. At present Saudi Arabia applies anti-dumping rules under the GCC umbrella; the GCC members defend their products as if they were one country, in a similar way to the EU. However, this umbrella body does not generally become involved in cases of anti-dumping when their products face actions from abroad. In the example of the case involving Saudi Arabia, India and Oman, anti-dumping duty was cancelled for Saudi Arabia only, although both countries were GCC members. This indicates that insufficient coordination and cooperation between the GCC countries with regard to anti-dumping cases. The GCC members would deal with anti-dumping cases as the EU community do. They deal with these particularly cases as one nation, which is give more strength to protect themselves and products as well. Based on founding research recommends to appropriate cooperation, it is time that the reality of issue be consider legally with amending the GCC framework to benefit all members of states under this organisation.

\section{Copyrights}

Copyright for this article is retained by the author(s), with first publication rights granted to the journal.

This is an open-access article distributed under the terms and conditions of the Creative Commons Attribution license (http://creativecommons.org/licenses/by/3.0/). 